\title{
The Adequacy of the Provisions of Jordanian Law to Regulate the Implied Expression of Will During Contracting
}

\author{
Dr. Shames ElDeen Qasim Al-Khazaleh \\ Doctor of Civil Law \\ Taibah University - Almadinat Almnawara - Saudi Arabia
}

\begin{abstract}
Legislation governing the expression of will during the contract, whether explicit or implicit, has agreed on considering them equal in terms of legal value, but they differ in terms of proof. This research will discuss the adequacy of the implicit expression of will during contracting. The researcher concluded that the expression of will, whether explicit or implicit, has the same validity in terms of their legal value, including tacit "silence." The research will include some legal and judicial applications on this subject.
\end{abstract}

Keywords: expression of will, implied expression, express expression, silence, tacit.

DOI: $10.7176 / \mathrm{JLPG} / 92-19$

Publication date: December $31^{\text {st }} 2019$

\section{Introduction}

Every social system based on its individuals who are considered his target, it exerts all efforts to achieve their interests and provide suitable services to them. The personality of these individuals can't be fully shaped unless they exercise their freedom by having a free independent will that is respected by both social ties and laws.

Every commitment based on consent and choice is compatible with the Law of nature because this law is established on the free will that should be respected by all. For this reason, laws and regulations stressed on the importance of the free will of individuals, they enhanced the respect of will among the individuals of the society. Laws also stressed on the importance of achieving the individuals free will in a way that does not contradict with the other freedom. Achieving the balance between free will and freedom respect among the individuals of a society lies on the responsibility of the legislator.

The French jurist "Duma" said: (If it is agreed, all that was agreed upon is the rule of law for the one who contracted.)which in Arabic it means (the contract is the contractor's law.) even if the free will and its consequences are guaranteed by the law, they are not absolute, it has limits that must be observed in order to achieve the public interest.

It should be noted, that all the western legal jurisprudence basis has rooted from the rulings decided by the Muslim jurists in their first idiosyncratic thinking, who stated that the abstract will of any external form is sufficient to establish a contract and determining its legal effects. The Messenger of Allah (peace be upon him) said: "the Muslims will be held to their conditions, except the conditions that make the lawful unlawful, or the unlawful lawful." Which is discussed in the jurisprudence under the violation of public order and public morals .

The principle of contractual freedom implies that a person does not abide by what his will is not willing to do, and unless a person expresses his will, law doesn't take it into consideration or dictates its legal effect. Therefore, the will should be expressed to have a legal effect. The will of an individual is expressed through an external appearance that a natural person takes to reveal his intention to contract.

The will is a psychological state that is not seen or appeared but is inherent in the soul like a fetus in the womb of his mother. That we do not notice his features until birth, he is like the expression of the will, if any verbal or behavioral expression appear from him, his features is determined.

Expressing the will is achieved through offer and acceptance, as the Jordanian Civil Code, Article (91) stipulates that "an offer and an acceptance each is an expression of will, used for initiating and what is made first is an offer while the second is acceptance. Since the principle of establishing a contract is consent, there is no specific form for expressing the will, and therefore the legislator specified the means of expressing will, for example, and not limited to, in Article (93) which stipulates: "the expression of the will shall be by word, writing, the customary sign, even from a person who is dub, the actual exchange denoting consent and by any other behavior which the circumstances leave no doubt of its indication of consent".

True will can be identified clearly through explicit expressions, while the implied expression needs more interpretation to convey the meaning of the real intended will through using indirect ways, which may sometimes lead to the difficulty to communicate the real intention.

According to the significant of this topic and the risk that may established as a result of violating the principle of consent and freedom to contract, the researcher decided to discuss this topic in detail from the legal aspect to remove any doubt covering this issue. 


\section{The significance of the study}

The significance of this study is based on the rule "if an explicit expression of a will has the legal value, an implicit expression of will is also having a legal value", even though an explicit expression indicates a direct will, while the implicit expression needs more thinking to interpret its implications by examining the surrounding circumstances of the concluded the contract.

\section{The Problem of the study}

The problem of the study lies in the answer of these two questions, Was the legislator successful when he equated the implicit expression of will with the explicit one in terms of its legal effects, despite their different clarity in expressing the will? And what is the value of a tacit or silence expressions in terms of its legal effects and its inequality with the implicit expression, despite the clear similarities between them?

Research Methodology. The research used the descriptive analytical approach.

The research Plan. Based on the foregoing, the research was divided into two topics, the first topic examines the implicit expression and its distinction from explicit and tacit "silence." The second topic discusses the applications of the legislative regulation of the implicit. expression as follows:

The First Topic: Implied and tacit expressions

The first section: the definition of implied expression and how to distinguish it from the explicit expressions.

1. Definition of the implicit expression

2. Distinguishing between the implied and the express expressions of will

The second section: Tacit "silence"

1. The definition of Tacit and its role in expressing will

2. Distinguishing implicit expression from silence.

The second topic: Forms of the legislative regulations of the implicit expression and its judicial applications.

The first section: Forms of the legislative organization.

1. The implicit approval in the suspended contract.

2. The implicit expression in terms of trial

3. The extension of the lease contract after the end of the period

4.Gift in real contracts (gift)

The second section: Judicial applications of implicit expression

Court of Cassation Resolution No. 663/97 / Bar Journal.

\section{The First Topic: Implied and tacit expressions}

Section One: The definition of implied expression and how to distinguish it from the explicit expressions

Law does not take the hidden will into consideration unless it is expressed, by interpreting Article (93) of the Jordanian Civil Code on how to express the will, we realize that the expression can be implied or expressed and on this basis we will discuss the implicit expression in terms of recognizing it and how it is similar to the explicit expression in the first section, and in the second section we will discuss silence.

\section{The definition of the implicit expression.}

The expression is implied if the actions of the contractor does not by itself indicate his will, but it can nevertheless be interpreted only on the assumption that this will exists.

If a person offers to sell something to another at a certain price and the offeree didn't show his acceptance explicitly, but he demonstrated a legal act indicating assent such as he used or sold it.

Likewise, if a person asked a greengrocer about the price of a fruit, and after he answered him, that person started eating the fruit without saying anything. ${ }^{1}$

Another case is that the tenant remains in the leased property after the specified lease term ends without objection by the lessor. ${ }^{2}$

In these three cases, the other party did not express his will explicitly, but his behavior can only be interpreted as an expression of the will. The behavior of the person who acted on the thing offered to him is explained as an assent. Similarly, the person who asked the seller for the price of the fruit after he knew the price, he ate the fruit. The act of eating the fruit indicates his assent to buy it at the price mentioned by the seller.

Article (93) of the Jordanian Civil Code clarifies that expressing the will can be achieved by conducting any other acts where the circumstances leave no doubt that it indicates consent. ${ }^{3}$

Accordingly, the expression of the will is implied if the behavior of the person indicates his consent even if

\footnotetext{
${ }^{1}$ Hakim, A (1993) Adequate Explanation of Jordanian Civil Law, Iraqi Civil Law, and Yemeni Civil Law in Obligations and Personal Rights, Part 1 in Sources of Commitment, First Edition, the mutual consent p141

${ }^{2}$ Mansour, A (2011) The General Theory of Obligations, Sources of Obligation, A Study in Jordanian and Egyptian Civil Law and Islamic Jurisprudence with Judicial Applications of the Cassation and Discrimination Courts, Dar Al-Thaqafa Publishing, 6th edition, p. 65

${ }^{3}$ Mansour,op. cit ,p142
} 
it is done indirectly, and after logical interpretation it can only be explained by assuming the existence of this will.

\section{Distinguishing between the implicit and the explicit expressions of will.}

Before distinguishing between the implicit and the explicit expressions, we should address a brief idea of the explicit expressions as a means of exposing the true will of the contractors.

Article (93) of the Jordanian Civil Code stipulated that "the expression of the will shall be by word, writing, the customary sign, even from a person who is dub, the actual exchange denoting consent and by any other behavior which the circumstances leave no doubt of its indication of consent. The expression of the will is clearly expressed if it is done by one of the means that demonstrates in its nature the will, according to a customary behavior among people. ${ }^{1}$

Based on above, we find that the difference between the implied and the expressed expression of will does not have any legal effect as the implied expression has the same legal force as of the expressed expression of will. But the difference between them lies in the ease or difficulty of proof. Whereas in any case if there is two the expressions of will; the implied and the expressed, the expression that will be deemed is the expressed because it is stronger in meaning and easily proved. Muslim jurists express this by saying: "no indication versus express."

The Jordanian legislator confirmed in Article (215) of the Civil Law that the explicit expression of will is differentiated from the implicit expression, not only in terms of the means of expressing the will which is; the word or writing, but also in indicating the form of tense, the Jordanian legislator emphasizes that the express expression must be in the form of the past in the first place and if it came in the form of the imperative mood or the present tense, it indicates the present situation.

This is confirmed by Article (91/2) of the Jordanian Civil Law, where it stipulates that "expression of will shall be made verbally or in writing and it may be in past tense, present tense or in imperative mood, if they are intended to denote the present, or by showing a customarily known sign, even it is made by a person other than mute, or by actual reciprocity denoting mutual agreement or by taking other steps that undoubted indication of mutual agreement".

If the wording of the expression comes in the future verbs, it is deemed as a promise, and this is confirmed by the Jordanian Civil Law in Article (92) which stipulates that " a future tense that gives the meaning of absolute promise causes the contract to come into being and indicates a binding promise if it tends to the intention of the contracting parties."

The wording of the expression is only conceivable by the explicit expressions. The legislator may sometimes prevent the contractors from resorting to the implied expressions in some contracts, and they are obliged to use the explicit expression to protect the interest of the parties. The expression may be determined in a certain way such as writing, for example, Article (5 / C-3) of the Landlords and Tenants Law No. (11) of $1994^{2}$ gave the landlord the right to request the eviction of the tenant from the rented premises if he rents part of premises to another person; allowed another person to occupy the rented property or if he has vacated it to another person without a written consent of the landlord. In these cases, the legislator specifically stressed on a written consent, because the expressed intention in the contract is more powerful than the implied one. Therefore, Muslim jurists said: (The explicit indication has stronger effect than the tacit indication.) ${ }^{3}$

Thus, the expressed intention is shown by demonstrating a clear behavior in a situation that reveals by itself the intent of the doer as customary among people. ${ }^{4}$ For example, if a person offered verbally or in writing to sell an offeree a house for a certain price. In this situation he shows an express intention. This situation reveals by itself the intent of the offeror in accordance to what is customary among the people. Likewise, a taxi driver who is waiting in a station for a passenger to hire his car. This situation took place in a familiar station for car renting, so this act indicates directly that the cab driver wishes to take someone with a well-known rental cost.

We concluded that, most of the means specified by Article (93) of the Jordanian Civil Code are suitable to be an implied and an expressed expression of will. Thus, if the act directly indicates the intent of the doer and it occurred in a familiar situation among people we are coming across the express expression, but if the situation doesn't imply the intent directly by itself or in accordance to what is common among people and it needs more interpretation, hence we are coming across an implied expression. It does not mean that writing for instance is the only valid expression for asserting the will or the intention, but it is also valid for the implied expression. This can be explained by referring to the decision of the Industrial and Commercial Court of First Instance in Yemen, where in a case that the plaintiff filed a lawsuit before the court requesting the defendants to hand over two cars they were with them as a result of commercial interaction held between the two parties. The defendants denied and before the court, the plaintiff proved his claim by submitting a document represented in an

\footnotetext{
${ }^{1}$ Sirhan,A,. Khater, N(1997) Jordanian Civil Law, Sources of Personal Rights, Obligations, Comparative Study, 1997, p 50

${ }^{2}$ Sirhan, op. cit p 51

${ }^{3}$ Sirhan \& Khater,op . cit ,p 51-52

${ }^{4}$ Sanhouri, A. (2011) Mediator in Explaining the New Civil Law, The Compliance Theory in General, Sources of Commitment, Part One,

University Publishing House.,A Part (1) p. 176.
} 
application was submitted by the defendants written on the top of the document, the sentence (nothing can be delivered.) The court obtained from this written statement an implied declaration from the defendants that they have the two cars accordingly the court issued its decision based on the written sentence. ${ }^{1}$

Considering a situation where its conditions imply with no doubts what is intended by is another form of expressing intent whether explicitly or implicitly.

Therefore, if the situation or the acted behavior is a customary behavior that is recognized clearly among people, then it is an explicit expression of intention. For example, if a merchant offered his goods with a price list to the public, it would be an express statement of the offer because it is a familiar act, but if there is some doubt it will be subject to negotiation. This is stipulated in Article (94/2) of the Jordanian Civil Code where sometimes the situation or an action doesn't appear by itself subject to disclosure of the consent nor is it familiar, but the intention can't be inferred without assuming the existence of this will as when the offeree used or sold the offered goods, in that situation it is an implied expression achieved by taking a positive attitude. 2

Section Two: Tacit / silence as an expression of will

After we have distinguished between the implied expression and the expressed expression, we will discuss the tacit intent in terms of its definition, its role in expressing the will and how to differentiate it from the implied expression.

A. The definition of tacit and its role in expressing the will.

The Jordanian legislator stipulated in Article (95/1) of the Civil Code that (Silence in case of need is an expression and shall be considered acceptance.)

Silence is considered acceptance if there is a previous dealings between the two parties and if the offer tends to be in favor of the person to whom it is made. What we benefited from the previous two texts is that silence is nothing, it is when a person refrains from speaking, that no assent will be inferred from his silence, in the second part of the previous article, it indicted that silence indicates acceptance according to the state of the speaker and if it tends to be in favor of the person to whom a gift or an amount of money are offered in condition he accepted it silently, and in case of previous dealings between the two parties. For example (if a retail seller used to buy his goods from the same wholesaler without any indication of assent, then if the retailer requested some goods from the wholesaler and he send the required goods without saying any thing, his silence is deemed consent). ${ }^{3}$

The Jordanian legislator has ignored the use of silence as a means of expressing the intent in Article (93) of the Civil Code. It should be noted that what is meant by the phrase (in case of need) is what is equivalent to in Western jurisprudence is tacit, which is suitable for expressing the consent.

Tacit expression is silence in situations where no words, either written or spoken, have been exchanged by the parties, nor specific acts carrying the implication of consent are performed by them, but an obligation will arise out of mere silence or inaction. In other words, not to speak or not to do, under certain circumstances, will be considered as evidence of consent. For example, a buyer has received the goods he purchased with a price list, including certain conditions for the deal, his silence about what came in that list for reasonable period of time estimated by the judge, is considered acceptance. ${ }^{4}$

From the foregoing it becomes evident that abstract silence doesn't mean or indicate anything, it is nothing, so that it is not appropriate for expressing the intent, for either the offer or the acceptance. On the other hand, tacit consent can be deemed acceptance if the situation or the state of the person lend support to the presumption. $^{5}$

After we gave a brief overview of the silence, there remains nothing but the distinction between silence/tacit and the implied expression, and this will be discussed through the following section:

B. Distinguishing between the tacit and the implied expression of will

The Jordanian legislator resolved the dispute about the interpretation of the nature of the consent determined by Article (2/95) and whether it is an express or implied consent. In the explanatory notes, it was mentioned that: A distinction must be made between the implied expression of intent and the mere silence, the implied expression is a positive situation, while silence is just a negative situation. The implied expression may accord to some conditions be offer and acceptable, but silence is unacceptable to be considered a positive conduct, but in some exceptional assumptions it may be considered consent. ${ }^{6}$

By this, the Jordanian legislator has joined lawmakers who consider that silence does not fall within the express or implied expressions but is rather an acceptance a matter of legal presumption. In the explanatory notes

\footnotetext{
${ }^{1}$ Qahtan (1991) Silence expressing will and its effect on behavior, a comparative study in Egyptian law, and its Yemeni counterpart compared to Islamic jurisprudence, first edition of the year, p. 669.

${ }^{2}$ Hakim, op . cit , p 178

${ }^{3}$ Mansour,op. cit ,p 66

${ }^{4}$ Hakim, op cit ,p175

5 Qahtan, op . cit , p105

${ }^{6}$ The Jordanian Civil Code ,Article (95/2)
} 
(The legislator has assumed that silence is considered an acceptance, but we see that what constituted acceptance are two cases. ${ }^{1}$

However, the researcher disagrees with that what has been said about not considering the tacit expression as an implied expression because when the expression is implied, if the behavior of the person did not directly indicate his will, but it is inferred from certain circumstances that support the assumption of the occurrence of the intention. It indicates that the person's behavior is abstract and can not indicate his will unless he passes through other circumstances that surrounded his behavior and does not to leave any room for doubt his actual will. This case is consistent with the silence that if it was abstract, it is not possible to express the will even in acceptance. The circumstances surrounding him lend support a supposed undoubtful acceptance. Accordingly, silence may be deemed as a means of the implied expression.

Will is seen in two ways in terms of its existence and in terms of its clarity. In terms of its existence, it is not incompatible with explicitly and implicitly as the means used to express it reveals if it is either expressed or implied. In terms of clarity, the will is divided into express intent and implied intent. The expressed intent focuses on the will itself, the means for expressing it and the extent of its significance and when the expression is explicit the will is expressed. While the expression is implicit if the will is implied, as for the will inherent in the soul it is always one and being explicit or implicit is due to the way it is expressed.

Both expressions are used to describe the will, and they need a means by which it can be expressed. And according to the clarity of this mean it is described as an explicit or implicit indication of the will. Is silence fit to be an adjective, and if it is, then what is the means by which it was described? And what does it describe? By answering these two question we can realize that silence is the adjective and the description at the same time, which is not in consistence with what the legislation and jurisprudence deemed acceptable. Accordingly, there is no expressions that indicates the will than the express and the implied expressions, whereas silence is an independent type of expression.

Silence is one of the means of expressing the will, but this means can't express the intent only by itself, but rather it needs other factors outside the will that reveals ambiguity and indicates it, after that can we consider silence as an implicit means? ${ }^{2}$

It is known that silence is resorted to for the purpose of the will and it extends to the factors and circumstances surrounding it, whether they are expressed or still ambiguous, because they are considered a rectifying element of silence, they indicate what the will seeks, its circumstances surrounds it like; the bracelet with the wrist, the soul and the body that in their meeting life is written, and by their separation it leads to death and the absence of life. These circumstances are very important, and we should study them well to see if they can express the will or not, if they can clearly express the will, they will be a means of expressing it, but if these circumstances are ambiguous and have unclear indication, then the indication of silence here is a kind of implied indication of the will.

The existence of silence depends on the quality of these circumstances, the extent of its ability to interpret it, if they can't express the will more interpretation and deduction is done as in the case of tacit consent, which doesn't express the will directly. The silence of the wholesaler towards the offer of the retail trader and sending him the required goods, is deemed assent, the surrounding circumstances resulted from a previous dealing between the two parties and the trust between them plays a major role in indicating the consent of the wholesaler and not waiting for his disclosure of acceptance. The acceptance in the previous situation showed an implied will because silence doesn't indicate consent but the circumstances which are represented by the trust and previous dealings played a role on expressing his will. In this case, both the tacit consent and the surrounding circumstances are taken into consideration by jurisdiction, the decision and its implications in such cases are based on the judge's discretion.

In conclusion, silence is surrounded by the situations that can be either described or ambiguous that creates an evident will that reveals the inner will, as it is a means of expressing it, and it is implicitly indicated in case of tacit consent, because the method of expression used is not the one that determines its nature that can only be known by reference to the content of the implicit expression.

We can't deny that silence is an exceptional and specific means used to express acceptance and without waiting for the offer, since every method has its nature and scope and the means vary it starts from verbal expressions, in writing, indication, to different positive situations and ends with silence. ${ }^{3}$

\footnotetext{
${ }^{1}$ Al-Alfy, M. (1997) applying the jurisprudence rule (not attributed to silence) in the Jordanian civil law Sharia and Law Studies Vol (24) No. (2)

${ }^{2}$ Qahtan p.105

${ }^{3}$ Qahtan Pp.695-700
} 


\section{The Second Topic: Legislative and judicial applications to express will Section One: legislative applications \\ 1. Authorization in the suspended contract.}

The suspended contract is a lawful contract that was suspended, for one of the reasons of non-enforcement, so the effects of its enforceability are suspended on the authorization of its owner. Article (177) of the Civil Code specified the cases of the suspended contract, which are; an unauthorized agent, an owner in his own property which is charged with a third party's right, a person who lacks legal capacity in his own property if his disposition is fluctuating between an advantage and disadvantage. When examining the expression of the will through the sale of the property of a third party as a disposition of an unauthorized person, Article (172) stipulated that:

a) The approval shall be expressed in action or in words that bear evidence of it explicitly or impliedly.

b) Silence shall be considered an approval if it indicates consent according to customary practice.

Accordingly, the approved will can be explicit, implicit or by silence. If an unauthorized person concluded a contract between a seller and a buyer, the contract in considered valid for the parties but it is invalid for the owner until he approved it.

However, the owner's behavior may not express his will directly, but the surrounding environment which is represented by giving the buyer private information about the sale indicates his acceptance in an implied will.

I think that silence in this situation has an explicit will and not implicit because it is described and has a direct indication of will.

\section{Expressing the sale on trial terms}

\section{- $\quad$ Selling on trial terms.}

It is the sale that the buyer tries the item to see the extent of its suitability, the availability of the required qualities or the extent of its suitability for him personally in order to purchase it. If a person purchases a car on the condition of the trial and specifies a period of one week for the trial, whereby the buyer is subject to the trial obligations, that is not to use the sale during the duration of the trial except to the extent required, if he exceeds this amount it is considered an implied acceptance. For example, if he travelled by the car outside Jordan or he sends it for maintenance this situation indicates his acceptance to purchase it. But what if the limited period for the trial ends and he remains silent. Article (471/1) stipulated that if the trial period has expired and the buyer remains silent while being able to test the sale, the silence is considered acceptance and the sale is mandatory.) After the end of the trial period, if the buyer does not express his refusal of the sale according to Article (1/471) while being able to try it, his silence will be condescended by his circumstances and clearly indicated his will, as he remains silence, knowing that it is considered acceptance and at a time she could refuse. Her silence here showed her intention directly in accordance to obligations of the law.

\section{The continuation of the lease contract after the end of the period.}

If the lease term expires and the tenant remains in the rented premises with the knowledge of the lessor and without his objection, then the lease is renewed implicitly with the same terms as the expired lease, except for the period. In this case, a new lease is based on conditions of the expired old lease, except for the condition of the period. The new lease is based on a double implied will from the lessor and the lessee, the tenant by remaining in the premises after the end of the original lease implicitly indicate his will to conclude the new lease and the lessor in turn does not refuse which also indicates his implied acceptance. ${ }^{1}$

\section{Gift in Real Contracts}

Article (558) provides (the gift is held in offer and acceptance and is completed by receipt), the gift in real contracts as indicated in the text of the mentioned article is approved in the condition of receiving the gift, that is considered a means of expressing the will.

Example: If a person donates a gold necklace to another and then the grantee receives and accept the necklace, is the method of receipt is an explicit or implicit expression of the will? In my opinion: The act of receiving the gift is considered a positive situation according to the customary among people and by law it is deemed an explicit expression of acceptance.

\section{Section Two: judicial applications}

The Court of Cassation decided in one of its verdict that (the partner in the joint money who does not own more than half the value of the rented property is authorized in the contract to rent his partner's share in the joint money pursuant to the provision of Article (1/171) of the Civil Law, and the contract is suspended on the partner's approval) .

The owners filing a lawsuit with their partner who signed the lease contract as plaintiffs is considered approval of them for the lease agreement pursuant to Article (1/175) of the Civil Law. The contract shall be deemed to be enforceable from the date of its issuance, and it shall be their right to file an eviction lawsuit

${ }^{1}$ Qahtan op. cit, p,98 
against the tenant for renting the real estate to others without a written consent of the owners.

\section{Conclusion}

The researcher concluded that in accordance to the Jordanian Civil Code that there are different forms of expressions used to indicate the will which are the express and implied. The researcher recommended that silence should be considered as a means of expressing the will and that Jordanian legislator should impeded it within the text on Article (93) of the Jordanian Civil Code.

\section{References}

Al-Alfy, M. (1997) applying the jurisprudence rule (not attributed to silence) in the Jordanian civil law Sharia and Law Studies Vol (24) No. (2)

Abdel-Baqi (1984) Encyclopedia of Egyptian Civil Law Theory of Contract and Individual Will is an In-depth and Comparative Study of Islamic Jurisprudence, Modern Book Writer, Kuwait

Hakim, A (1993) Adequate Explanation of Jordanian Civil Law, Iraqi Civil Law, and Yemeni Civil Law in Obligations and Personal Rights, Part 1 in Sources of Commitment, First Edition

Mansour, A., M (2014) The General Theory of Waltz, Sources of Commitment, A Study in the Egyptian and Egyptian Civil Law and Islamic Jurisprudence with judication Applications, the Courts of Self and Discrimination, Darat Al-Thaqaf Publishing

Qahtan, A, M (1991) Silence expressing the will and its effect on behaviors A study in the Egyptian civil law and its right counterpart compared to Islamic jurisprudence $\mathrm{PhD}$ thesis. First edition

Sanhouri, A. (2011) Mediator in Explaining the New Civil Law, The Compliance Theory in General, Sources of Commitment, Part One, University Publishing House.

Sarhan, A and Khater (1997) Explaining the Jordanian Civil Law Sources of Personal Rights (Obligations), A Comparative Study, First Edition 